\title{
Physiological and molecular effects associated with palladium treatment in Pseudokirchneriella subcapitata
}

\author{
Candida Vannini ${ }^{a}$, Guido Domingo ${ }^{a}$, Milena Marsoni ${ }^{a}, *$, Alessandro Fumagalli ${ }^{\mathrm{b}}$, Raffaele Terzaghi $^{\mathrm{b}}$, \\ Massimo Labrac ${ }^{c}$, Fabrizio De Mattia ${ }^{c}$, Elisabetta Onelli ${ }^{\mathrm{d}}$, Marcella Bracale ${ }^{\mathrm{a}}$ \\ a Dipartimento Ambiente, Salute, Sicurezza, Università degli Studi dell'Insubria, via G.B. Vico 46, 21100 Varese, Italy

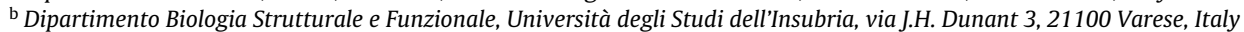 \\ c Dipartimento di Biotecnologie e Bioscienze, Università degli Studi di Milano Bicocca, Piazza della Scienza 2, 20126 Milano, Italy \\ ' Dipartimento di Biologia, Università degli Studi di Milano, Via Celoria 26, 20133 Milano, Italy
}

\section{A R T I C L E I N F O}

\section{Article history:}

Received 6 September 2010

Received in revised form

23 December 2010

Accepted 11 January 2011

\section{Keywords:}

Palladium

Pseudokirchneriella subcapitata

AFLP

2-DE

Mass spectrometry

\begin{abstract}
A B S T R A C T
Human activities have increased the levels of environmental palladium (Pd) worldwide. Due to the growing evidence of its toxicity, Pd pollution has become the focus of serious concern. Several studies have given an account of the increasing concentration of Pd in aquatic ecosystems.

The aim of the current study is to analyze the physiological and molecular effects induced by Pd on freshwater unicellular green algae. To do this, Pseudokirchneriella subcapitata (P. subcapitata) was exposed in vitro to different concentrations $\left(0.1,0.25\right.$ and $\left.0.5 \mathrm{mg} \mathrm{l}^{-1}\right)$ of $\mathrm{K}_{2} \mathrm{PdCl}_{4}$, a soluble salt of $\mathrm{Pd}$, corresponding to $0.03,0.075$ and $0.15 \mathrm{mg} \mathrm{l}^{-1}$ of Pd. The uptake and the effects on algal growth and morphology were determined. The main results are that Pd is able to induce damage in P. subcapitata at a concentration of $0.1 \mathrm{mgl}^{-1}$ of $\mathrm{K}_{2} \mathrm{PdCl}_{4}$, with the damage becoming more evident at a concentration of $0.25 \mathrm{mg} \mathrm{l}^{-1}$ of $\mathrm{K}_{2} \mathrm{PdCl}_{4}$; at a concentration of $0.5 \mathrm{mg} \mathrm{l}^{-1}$ of $\mathrm{K}_{2} \mathrm{PdCl}_{4}$, cellular degeneration occurs. The main cellular target of Pd is the chloroplast, as shown by TEM and proteomic analysis. TEM analysis also showed accumulation of precipitates, probably of $\mathrm{Pd}$, in the chloroplasts, although further experiments are necessary to confirm that these are Pd-precipitates. Amplified fragment length polymorphism analysis (AFLP) demonstrated that Pd, even at the lowest concentration tested, induced randomly distributed DNA changes either directly or indirectly in the algal genome and that oxidative processes were involved.
\end{abstract}

(C) 2011 Elsevier B.V. All rights reserved.

\section{Introduction}

Platinum group elements (PGEs) include platinum (Pt), palla$\operatorname{dium}(\mathrm{Pd})$, rhodium $(\mathrm{Rh})$, iridium (Ir), osmium (Os) and ruthenium (Ru). Naturally present at very low concentrations, PGEs are progressively accumulating in the environment. In fact, PGEs are used in an increasing number of applications (in the chemical, electrical, electronic and glass industries; in the manufacture of jewellery; in medicine). At present, the major source of Pt, Pd and Rh is automotive catalytic converters. The three metals are released with catalyst aging, essentially as metal particles bonded to fragments of the ceramic support as a consequence of surface abrasion during car operation (Gomez et al., 2002; Durand et al., 2008). PGE accumu-

Abbreviations: Pd, palladium; 2-DE, two-dimensional electrophoresis; Chla/b, chlorophyll $a / b ; \mathrm{MS} / \mathrm{MS}$, tandem mass spectrometry; LC-ESI-MS/MS, liquid chromatography-electro spray tandem mass spectrometry; PGEs, platinum group elements.

* Corresponding author. Tel.: +390332 421523.

E-mail address: milena.marsoni@uninsubria.it (M. Marsoni). lation has been reported in photosynthetic organisms (Ely et al., 2001; Zechmeister et al., 2006; Pan et al., 2009), in zebra mussels (Zimmermann et al., 2005), in raptors (Jensen et al., 2003; Ek et al., 2004), and in human urine (Bocca et al., 2004).

Recent studies have clearly shown that Pd concentrations in particular have increased over time, reaching levels up to several hundreds of $\mathrm{ng} \mathrm{g}^{-1}$ in some road dust samples (Ravindra et al., 2004), so that the metal is now the main component of trafficrelated pollution (Zereini et al., 2007). These results are consistent with the increasing availability of diesel cars in which the recent evolution of design tends to replace the platinum with palladium in the catalyst (Fumagalli et al., 2010). Experiments made on road dust samples with both deionised water and simulated rainwater show that the solubility rate for Pd is relatively rapid (in comparison to Pt and $\mathrm{Rh}$ ) with 6\% of the metallic palladium solubilised in $15 \mathrm{~h}$ (Parry and Jarvis, 2006). Furthermore, weathering of palladium can be facilitated by the presence of chlorides that greatly lower its reduction potential (Handbook of Chemistry and Physics - CRC); in other words, formation of the $\left[\mathrm{PdCl}_{4}\right]^{2-}$ complex can greatly promote the Pd solubilisation in water. High levels of Pd have been found in several water ecosystems: up to $38.7 \mathrm{ng} \mathrm{g}^{-1}$ in sediments 
of the Mölndal river and up to $19.93 \mathrm{ng} \mathrm{g}^{-1}$ in Boston Harbor surface sediment (Moldovan et al., 2007; Tuit and Ravizza, 2000). Lower, but significant concentrations of Pd have been detected in solution even in flowing waters, such as the Rhein river in Germany (0.4 $\mathrm{ng} \mathrm{l}^{-1}$, ppt) (Ravindra et al., 2004) and in the water entering the Varese sewage treatment plants (up to $2 \mu \mathrm{gl}^{-1}$, ppb) (Fumagalli, work in progress, 2010).

Palladium is even more critical than Pt and Rh with regard to its biological effects (Jarvis et al., 2001). It is taken up by plants and animals and shows negative effects even in very low concentrations (Battke et al., 2008; Hoppstock and Sures, 2004). In addition, this metal possesses a high affinity for the binding of DNA through its interactions with phosphate residues, inducing the formation of macrochelates. It has been shown that $\mathrm{K}_{2} \mathrm{PdCl}_{4}$, a water soluble salt of $\mathrm{Pd}$, reacts with natural and synthetic nucleic acids in vitro, producing profound rearrangements in their structure (Fomina et al., 2002).

Information about the mechanisms involved in the response of freshwater unicellular algae to Pd stress is practically nonexistent, despite their importance as primary producers and biological monitoring organisms. The aim of this study was to investigate the physiological and molecular effects of in vitro $\mathrm{K}_{2} \mathrm{PdCl}_{4}$ treatment on the unicellular green microalgae Pseudokirchneriella subcapitata. The relationship between chemical pollution and alterations in the biochemical processes of exposed organisms is of high importance in environmental research. Molecular data can provide information for understanding the environmental impact of chemical stressors and help to find suitable biomarkers for exposure. Due to its sensitivity (Mayer et al., 1997; Gueguen et al., 2003), P. subcapitata is the model organism for freshwater algae and is widely used in the algal growth inhibition test of the Organisation for Economic Co-Operation and Development and US Environmental Protection Agency.

We focused our attention on concentrations of $0.1,0.25$ and $0.5 \mathrm{mg} \mathrm{l}^{-1}$ of $\mathrm{K}_{2} \mathrm{PdCl}_{4}$, corresponding to $0.03,0.08$ and $0.16 \mathrm{mg} \mathrm{l}^{-1}$ of $\mathrm{Pd}$. These concentrations are quite high with respect to the concentrations of soluble Pd found in the environment, but are similar to the total load of Pd (300-400 $\left.\mathrm{ng} \mathrm{g}^{-1}\right)$ that can be found in the road dust (Ravindra et al., 2004; Fumagalli et al., 2010).

Our results indicate that Pd induced massive damage in $P$. subcapitata at both the growth and the morphological levels. Chloroplasts are the main Pd target, as shown by TEM, proteomic, and pigment analysis. TEM data showed electron-opaque precipitates visible in the chloroplast membranes; their number was proportional to the amount of Pd administered. These precipitates were also observed in samples that were stained with uranyl acetate and lead citrate excluded from the procedure for electron microscopy, suggesting that they could be Pd-derived deposits. Finally, amplified fragment length polymorphism (AFLP) analysis (Vos et al., 1995), a robust and highly informative DNA fingerprinting method, revealed that $\mathrm{Pd}$ is able to induce a great deal of randomly distributed DNA damage in the algal genome.

\section{Materials and methods}

\subsection{Synthesis of $\mathrm{K}_{2} \mathrm{PdCl}_{4}$}

A piece of Pd foil (99.9\%, $1 \mathrm{~mm}$ thick, $2.615 \mathrm{~g}, 24.57 \mathrm{mmol}$ ) was treated in an Erlenmeyer flask with aqua regia (a mixture of concentrated nitric acid and hydrochloric acid of $1: 3,3 \mathrm{ml}$, and $9 \mathrm{ml}$, respectively) and placed on a hot plate to yield, within $1 \mathrm{~h}$ with gentle boiling, a dark red solution. The solution was cautiously reduced almost to dryness and treated with $\mathrm{HCl}(1-2 \mathrm{ml})$ to decompose all the excess nitric acid; this operation was repeated twice until the brown fumes subsided and then the solution was diluted with water to ca. $100 \mathrm{ml}$ and boiled. After addition of $\mathrm{KCl}(3.686 \mathrm{~g}$, $49.44 \mathrm{mmol}$ ), the hot solution was filtered through a fritted glass funnel to remove some minimal insoluble material, which was discarded. The clear solution was evaporated until incipient formation of a crystalline precipitate and then slowly cooled at room temperature. Filtration and drying with air flow through a fritted glass funnel yielded a first fraction of pure $\mathrm{K}_{2} \mathrm{PdCl}_{4}$ as fulvous crystals (yield ca. 5.0 g, >60\%). Anal.: \% Found (calcd): Pd, 32.7 (32.6). Concentration of the mother liquor yielded a second, less pure fraction of the product.

\subsection{Algal culture conditions and palladium treatment}

The axenic $P$. subcapitata Hindák strain was obtained from the Collection of Algal Cultures, Göttingen, Germany (SAG 61.81, http://www.epsag.uni-goettingen.de/html/sag.html). The stock algal cultures were maintained under gentle and continuous shaking $(100 \mathrm{cpm})$, controlled temperature $\left(23 \pm 2{ }^{\circ} \mathrm{C}\right)$ and constant light irradiance $(4000 \pm 500$ lux $)$. Cultures were periodically checked for contamination on nutrient agar plates. The cultures were subcultured weekly into 250 -ml flasks containing $150 \mathrm{ml}$ of sterile algal culture medium (Charles and Searle, 1991; USEPA, 1994 ) to obtain an initial concentration of $2 \times 10^{5}$ cell ml$^{-1}$. Only cultures in logarithmic phases were used for inoculation, and for each experiment six flasks were inoculated for untreated (control) and treated cells. Algae were treated with $\mathrm{K}_{2} \mathrm{PdCl}_{4} 15 \mathrm{~h}$ after inoculation to allow cell adaptation before treatment. We treated samples with $0.1,0.25$ and $0.5 \mathrm{mg} \mathrm{l}^{-1}$ of $\mathrm{K}_{2} \mathrm{PdCl}_{4}$, corresponding, respectively, to $0.03,0.075$ and $0.15 \mathrm{mg} \mathrm{l}^{-1}$ of Pd. Controls consisted of untreated cells. Cell proliferation was recorded over three time points in a $72 \mathrm{~h}$ exposure period, and algal density was determined by spectrophotometric measurement at $750 \mathrm{~nm}$. Measurements were repeated three times for each sample. After $72 \mathrm{~h}$, algal cells were collected, washed three times with $0.1 \mathrm{M}$ EDTA MilliQ and immediately used for pigment analysis or stored at $-80^{\circ} \mathrm{C}$ until for later use in AFLP and 2DE analysis. For atomic absorption, the samples were lyophilized (VirTis 8L Benchtop Freeze Dryer) before freezing.

\section{3. $\mathrm{K}_{2} \mathrm{PdCl}_{4}$ uptake by algae}

Dried samples were treated with $1 \mathrm{ml}$ of $\mathrm{HCl}$ and $1 \mathrm{ml}$ of hydrogen peroxide $\left(\mathrm{H}_{2} \mathrm{O}_{2}\right)$ and almost reduced to dryness on a hotplate; after addition of some $\mathrm{HCl}(0.2-1 \mathrm{ml}$, to reach a final content of approximately $1 \%$ ), the samples were transferred to a suitable volumetric flask (generally a $20-\mathrm{ml}$ one), making up the volume with Milli-Q water. Blanks were made with the same solvents and chemicals employed in the treatment and digestion of the samples, or with just $1 \% \mathrm{HCl}$ in Milli-Q water.

All the chemicals used for the sample pre-treatments and mineralization were for metal trace analysis (or equivalent) grade: Milli-Q water (Millipore purification system); hydrochloric acid (Baker 9530 for metal trace analysis, 36.5-38\%); nitric acid (Baker 9598 for metal trace analysis, 69-70\%); and $\mathrm{H}_{2} \mathrm{O}_{2}$ (Fluka 95313, not stabilized, 30\%). Calibration standard solutions were prepared daily from $1000 \mathrm{mgl}^{-1}$ standard solutions of Pd purchased from $\mathrm{J}$. T. Baker Instra-Analyzed.

Measurements were performed on a Thermo-Electron atomic absorption spectrometer. Levels of Pd [ng ml${ }^{-1}$ (ppb)], were determined using a graphite furnace (GFAA) coupled with Zeeman background correction. Thermal ramps with double drying and washing steps were specifically developed (Table 1). Wavelength, bandpass, and all other instrumental parameters were set according to the usual recommendations of the instrument Cookbook. 
Table 1

Thermal ramps for Pd GFAA.

\begin{tabular}{lccc}
\hline & Temp. $\left({ }^{\circ} \mathrm{C}\right)$ & Time $(\mathrm{s})$ & Ramp $\left({ }^{\circ} \mathrm{Cs}^{-1}\right)$ \\
\hline Drying & 90 & 5 & 5 \\
& 115 & 20 & 2 \\
Ashing & 800 & 5 & 50 \\
& 1200 & 30 & 100 \\
Atomization & 2500 & 3 & 0 \\
Cleaning & 2600 & 6 & 0 \\
\hline
\end{tabular}

Note the double drying and ashing steps.

\subsection{Electron microscopy}

Cells were included in 5\% sodium alginate and then fixed in $3 \%$ glutaraldehyde. After a few days, the samples were repeatedly rinsed in $0.1 \mathrm{M}$ cacodylate buffer and post-fixed in cacodylate buffer containing $1 \%$ osmium tetroxide, $\mathrm{pH} 6.9$, for $2 \mathrm{~h}$ at $4{ }^{\circ} \mathrm{C}$. Samples were then dehydrated with increasing concentrations of ethanol and embedded in Spurr resin. Ultra-thin sections ( $80 \mathrm{~nm}$ ), obtained using a Reichert Jung Ultracut E microtome, were stained with 3\% uranyl-acetate and lead citrate and observed with an EFTEM LEO $912 \mathrm{AB}$ transmission electron microscope (Zeiss) working at $80 \mathrm{kV}$.

\subsection{Photosynthetic pigment analysis and Fv/Fm measure}

Chlorophyll $a$ (Chla), chlorophyll $b$ (Chlb) and carotenoids were extracted from algal samples in dimethylformamide (DMF), as described by Moran and Porath (1980). In brief, algal suspensions were harvested by centrifugation $(5000 \times g)$ at $4{ }^{\circ} \mathrm{C}$ for $15 \mathrm{~min}$. Pellets were resuspended in $1 \mathrm{ml}$ of algal culture medium. Then, $200-\mu$ l aliquots were incubated overnight in $800 \mu l$ of DMF in the dark at $4{ }^{\circ} \mathrm{C}$. All steps were performed in the dark at $4{ }^{\circ} \mathrm{C}$. All the absorption spectra were recorded from 350 to $800 \mathrm{~nm}$, with a $0.5 \mathrm{~nm}$ bandwidth and a scan rate of $200 \mathrm{~nm} \mathrm{~s}^{-1}$.

Pigment concentration was calculated using the following equations (Porra et al., 1989):

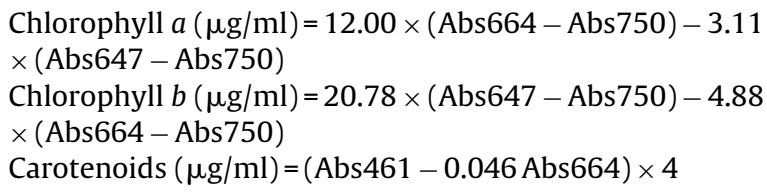

Pigment content was normalized by dividing with cell number. Measures were repeated three times for each sample.

Assay of photosystem II activity was performed by fast chlorophyll fluorescence according to Strasser et al. (1995), using the Handy-Pea from Hansatech (King's Lynn, England). $25 \mathrm{ml}$ of cells suspension was filtered by Millipore filter system on Millipore Durapore filter (47-mm diameter, $0.22 \mu \mathrm{m}$ pore size). Filters were fixed in the leaf clips of the Handy-Pea and incubated in darkness for $20 \mathrm{~min}$ in Petri to prevent dehydration. For controls and treatments, a minimum of 5 parallel measurements each were taken.

\subsection{DNA extraction and AFLP analysis}

DNA was extracted using the Plant Genomic DNA Miniprep Kit (Sigma-Aldrich), starting from $100 \mathrm{mg}$ of fresh algae material $(P$. subcapitata is diploid with modest DNA content: $C$ value $=0.2 \mathrm{pg}$ ). DNA concentration was estimated by electrophoresis on $0.7 \%$ of agarose gel in TAE buffer for $1 \mathrm{~h}$ at $100 \mathrm{mV}$. The gel was stained in $0.5 \mathrm{mg} / \mathrm{ml}$ of ethidium bromide and analyzed with a Gel Doc 2000 (Biorad, USA). The DNA concentration of each sample was obtained by comparing ethidium bromide-stained band intensities with the $\lambda$ DNA standard. AFLP was performed as described in Vos et al. (1995), except that genomic DNA (100 ng) was digested
Table 2

Sequences of adapters and primers used for AFLP analysis.

\begin{tabular}{lll}
\hline Type & Name & DNA sequence \\
\hline EcoRI adapter & & 5'-CTC GTA GAC TGC GTA CC-3' \\
& & 3'-CAT CTG ACG CAT GGT TAA-5' \\
MseI adapter & & 5'-GAC GAT GAG TCC TGA G-3' \\
& & 3'-TAC TCA GGA CTC AT-5' \\
EcoRI + 1 primer & E00 & 5'-GAC TGC GTA CCA ATT C-3' \\
MseI + 1 primer & M00 & 5'-GAT GAG TCC TGA GTA A-3' \\
EcoRI + 3 primers & E32 & 5'-GAC TGC GTA CCA ATT CAA C-3' \\
& E38 & 5'-GAC TGC GTA CCA ATT CAC T-3' \\
MseI + 3 primers & M38 & 5'-GAT GAG TCC TGA GTA AAC T-3' \\
& M42 & 5'-GAT GAG TCC TGA GTA AAG T-3' \\
\hline
\end{tabular}

(2 h) with EcoRI ( $1 \mathrm{U})$ and MseI ( $1 \mathrm{U})$. The DNA fragments were ligated (with T4-DNA ligase) to EcoRI ( $2.5 \mathrm{pmol})$ and MseI ( $25 \mathrm{pmol})$ adapters in a final volume of $40 \mu$ l. Ligation reaction was performed at $22{ }^{\circ} \mathrm{C}$ for $2 \mathrm{~h}$. This mixture was used as the template in the preamplification reaction containing DNA primers E00 and M00 (Table 2) complementary to the core of the EcoRI and MseI adapter, respectively. The $50-\mu \mathrm{l}$ amplification mixture contained $30 \mu \mathrm{l}$ of digested/ligated DNA, $50 \mathrm{ng}$ of the selected primers, $200 \mathrm{mM}$ of each of the 4 dNTPs, $0.5 \mathrm{U}$ of Dynazyme II (Finnzymes, Finland) and $5 \mu \mathrm{l}$ of Dynazyme buffer. After $2 \mathrm{~min}$ at $94^{\circ} \mathrm{C}$, amplification was carried out for 20 cycles of denaturation ( $45 \mathrm{~s}$ at $94^{\circ} \mathrm{C}$ ), annealing $\left(30 \mathrm{~s}\right.$ at $\left.50^{\circ} \mathrm{C}\right)$ and extension $\left(1 \mathrm{~min}\right.$ at $\left.72^{\circ} \mathrm{C}\right)$. After a final elongation step ( $7 \mathrm{~min}$ at $72^{\circ} \mathrm{C}$ ), the preamplification product was diluted $1: 20$. The PCR products were amplified in a second round with primers containing selective bases (Table 2); this was carried out using primer pairs E32-M38, E32-M42, E38-M38, and E38-M42. The EcoRI-primer was labeled using fluorescent 6-carboxy fluorescein (6-FAM) on the $5^{\prime}$ nucleotide. The temperature profile for this step was the following: one cycle of $5 \mathrm{~min}$ at $94^{\circ} \mathrm{C}$, followed by 10 cycles of $30 \mathrm{~s}$ at $94^{\circ} \mathrm{C}, 1 \mathrm{~min}$ at $65^{\circ} \mathrm{C}$ (for the first cycle, subsequently reduced each cycle by $1^{\circ} \mathrm{C}$ for the next nine cycles), and $1 \mathrm{~min}$ at $72^{\circ} \mathrm{C}$. This was followed by 25 cycles of $30 \mathrm{~s}$ at $94{ }^{\circ} \mathrm{C}, 1 \mathrm{~min}$ at $56^{\circ} \mathrm{C}$ and $1 \mathrm{~min}$ at $72^{\circ} \mathrm{C}$, before the PCR was terminated with a final incubation step of $10 \mathrm{~min}$ at $72^{\circ} \mathrm{C}$. The amplified fragments were fractionated and detected with an ABI PRISM 3130 Genetic Analyzer (Applied Biosystems Inc., Foster City, CA, USA) with Data Collection software, version 3.0 (ABI). AFLP analysis was performed with GeneScan Analysis Software, version 4.0 (ABI), and the data were assembled in binary format. Fragments were resolved using capillary electrophoresis.

Each AFLP fragment was scored as a binary character for the absence $(-)$ or presence $(+)$. Similar genotypes were defined as "a" $(\mathrm{a}=++)$ or "d" $(\mathrm{d}=--)$, while dissimilar genotypes were defined as " $b$ " $(b=+-)$ or "c" $(c=-+)$. The algorithm used to define genetic similarity was the simple matching (SM) coefficient:

$\mathrm{SMij}=\mathrm{a}+\frac{\mathrm{d}}{\mathrm{a}}+\mathrm{b}+\mathrm{c}+\mathrm{d}$,

where "a" and "d" are the numbers of bands present or absent, respectively. Data were analyzed by the NTSYS-pc computer software, and the matrices of similarity were then analyzed using the UPGMA cluster method (Rohlf, 1993).

\subsection{Protein sample preparation}

Frozen cell pellets were homogenised in liquid nitrogen using a mortar and pestle, with addition of quartz sand. Soluble proteins were extracted in four volumes $(\mathrm{w} / \mathrm{v})$ of buffer containing $500 \mathrm{mM}$ Tris- $\mathrm{HCl} \mathrm{pH} 8,700 \mathrm{mM}$ sucrose, $10 \mathrm{mM}$ EDTA, $4 \mathrm{mM}$ ascorbic acid, 0.4\% 2-mercaptoethanol, 0.2\% Triton X-100 10\%, $1 \mathrm{mM}$ phenylmethanesulfonyl fluoride (PMSF; Sigma, St. Louis, MO, USA), $1 \mu \mathrm{M}$ Leupeptin (Fluka, Stenheim, Germany), and $0.1 \mathrm{mg} \mathrm{ml}^{-1}$ Pefabloc (Fluka, Stenheim, Germany) and were sub- 
sequently stirred for $30 \mathrm{~min}$ at $4{ }^{\circ} \mathrm{C}$. After sonication three times for $10 \mathrm{~s}$ with intervals of $30 \mathrm{~s}$, the samples were centrifuged at $13,000 \times \mathrm{g}$ for $20 \mathrm{~min}$ at $4{ }^{\circ} \mathrm{C}$. An equal volume of phenol saturated with Tris- $\mathrm{HCl} 0.1 \mathrm{M} \mathrm{pH} 8$ was added to the supernatant, and the phases were separated by centrifugation at $5000 \times \mathrm{g}$ for $20 \mathrm{~min}$ at $4{ }^{\circ} \mathrm{C}$. The proteins were precipitated by adding five volumes of cold $0.1 \mathrm{M}$ ammonium acetate in methanol to the phenol phase, vortexing and incubating overnight at $-20^{\circ} \mathrm{C}$. The precipitates were recovered by centrifuging at $13,000 \times g$ for $30 \mathrm{~min}$, washed with ammonium acetate in methanol and with acetone $80 \%$, and then resuspended in the IEF solubilisation buffer ( $7 \mathrm{M}$ urea, $2 \mathrm{M}$ thiourea, 4\% 3-[(3-cholamidopropyl) dimethylammonio]-1propanesulfonate (CHAPS), $50 \mathrm{mg} \mathrm{ml}^{-1}$ dithiothreitol (DTT)). After sample clarification at $13,000 \times \mathrm{g}$ for $10 \mathrm{~min}$, the protein concentration was measured by the Bio-Rad protein assay (Hercules, CA, USA), using bovine serum albumin as a standard. The samples were directly loaded for isoelectrofocusing (IEF) or stored in aliquots at $-80^{\circ} \mathrm{C}$ until use.

Three independent protein extractions were performed, and the typical yield was $450 \mu \mathrm{g}$ of protein $\mathrm{g}^{-1}$ (fresh weight) from both treated and control cells.

\subsection{Two-dimensional IEF/SDS-PAGE}

IEF was carried out with $600 \mu \mathrm{g}$ of soluble protein extract using an immobilized 4-7 pH gradient (Immobiline DryStrip, $13 \mathrm{~cm}$; Amersham Biosciences, Uppsala, Sweden). The strips were rehydrated in the IPGphor system (Amersham Biosciences, Bucks, UK) for $1 \mathrm{~h}$ at $0 \mathrm{~V}, 20^{\circ} \mathrm{C}$ and $10 \mathrm{~h}$ at $30 \mathrm{~V}, 16^{\circ} \mathrm{C}$ with a solubilisation buffer containing $7 \mathrm{M}$ urea, $2 \mathrm{M}$ thiourea, $4 \%$ CHAPS, $50 \mathrm{mg} / \mathrm{ml}$ of DTT, $0.5 \%$ of carrier ampholyte (3-10 NL IPG buffer; Amersham Biosciences, Uppsala, Sweden), bromophenol blue $0.005 \%$ and the protein extracts. IEF was performed at $16^{\circ} \mathrm{C}$ in the IPGphor system (Amersham Biosciences, Uppsala, Sweden) for $4 \mathrm{~h}$ at $200 \mathrm{~V}$, from 200 to $3500 \mathrm{~V}$ in $30 \mathrm{~min}$ (gradient), $3 \mathrm{~h}$ at $3500 \mathrm{~V}$, from 3500 to $8000 \mathrm{~V}$ in $30 \mathrm{~min}$ (gradient), after which the run was continued at $8000 \mathrm{~V}$ to give a total of $70 \mathrm{kVh}$.

Each focused strip was equilibrated for $30 \mathrm{~min}$ against $6 \mathrm{M}$ urea, 30\% glycerol, 2\% SDS, $50 \mathrm{mM}$ Tris- $\mathrm{HCl} \mathrm{pH} 8.8,2 \%$ DTT and then a further 30 min with the substitution of the DTT with $2.5 \%$ iodoacetamide in the equilibration buffer. The equilibrated strips were placed on top of vertical $12.5 \%$ polyacrylamide gels (acrylamide/PDA $12.5 \%$ T, 2.6\% C, 0.375 M Tris-HCl pH 8.8, TEMED 0.05 $(\mathrm{v} / \mathrm{v})$, APS $0.1 \%(\mathrm{p} / \mathrm{v}))$. The molecular weight markers, covering a $10-250 \mathrm{kDa}$ range, were run on the acidic side of each gel. Electrophoresis was performed at $4{ }^{\circ} \mathrm{C}$ in a Laemmli running buffer (25 mM Tris- $\mathrm{HCl} \mathrm{pH} 8.3,192 \mathrm{mM}$ glycine, $0.1 \% \mathrm{SDS}$ ) for $30 \mathrm{~min}$ at $15 \mathrm{~mA} /$ gel, then at $45 \mathrm{~mA} /$ gel until the dye front reached the bottom of the gel. Each extraction was analyzed by three gel replicates.

\subsection{Staining and analysis of 2-D gels}

Proteins were detected with colloidal Coomassie brilliant blue (CBB) modified (Aina et al., 2007). Thereafter, gels were digitalized by ImageScanner (Amersham Bioscience, Uppsala, Sweden). Image and data analysis of the scanned (300 dpi, 16-bit greyscale pixel depth) gels as TIFF files was performed using the Image Master 2D Platinum imaging software, version 5.0, which allows spot detection, spot matching among multiple gels, background subtraction and quantitation. For this purpose, data were normalized by expressing protein abundance as a percentage of spot volume relative to the volume of total protein in the gel (vol.\%). 2D gel replicas for each condition tested were averaged, and the resulting gels contained only spots present in all the replicates. The average gels were compared, and only proteins with a fold change of \pm 1.5 , significant in Student's $t$-test at a level of $95 \%$, were accepted as differentially expressed. These spots were selected for MS/MS analysis.

\subsection{Protein in-gel digestion, mass spectrometry analysis and protein identification}

Selected spots were excised from 2D-gels and stored in 50\% ethanol at $4{ }^{\circ} \mathrm{C}$ until digestion. Spot digestion was performed as described in Marsoni et al. (2008) with the same modifications. The gel pieces were washed in $\mathrm{H}_{2} \mathrm{O}$ for 5 min and subsequently in $50 \%$ acetonitrile (ACN) for the same amount of time. Then fragments were dehydrated for $5 \mathrm{~min}$ in 100\% ACN, rehydrated for $5 \mathrm{~min}$ in $100 \mathrm{mM}$ ammonium bicarbonate and finally incubated in $50 \mathrm{mM}$ ammonium bicarbonate $/ 50 \%$ ACN for $15 \mathrm{~min}$. The gel pieces were dried under vacuum on a centrifugal evaporator. For protein digestion, trypsin solutions (Sequencing Grade Modified Trypsin V5111, Promega, Madison) $12.5 \mathrm{ng} \mu \mathrm{l}^{-1}$ in $25 \mathrm{mM}$ ammonium bicarbonate, $\mathrm{pH} 7.8$, containing $2.5 \mathrm{mM} \mathrm{CaCl}_{2}$ (digestion buffer), was added to each sample. After an incubation of $120 \mathrm{~min}$ at $4{ }^{\circ} \mathrm{C}$, the supernatants were replaced with digestion buffer and the samples were incubated for $16 \mathrm{~h}$ at $37^{\circ} \mathrm{C}$. Peptides were extracted as previously described and dissolved in $25 \mu \mathrm{l}$ of $0.1 \%$ formic acid before analysis.

The extracted tryptic fragments were analyzed by MS/MS after reverse phase separation of peptides (Liquid Chromatography-Electro Spray Tandem Mass Spectrometry, LC-ESI-MS/MS) as described in Vannini et al. (2009).

Protein identifications were conducted by correlation of uninterpreted tandem mass spectra to the entries of a non-redundant and/or EST-viridiplantae protein database using MASCOT open source (http://www.matrixscience.com). Unsuccessful protein identifications or those with borderline statistical confidence were submitted to de novo sequencing. MS/MS spectra of these proteins were de novo interpreted by PepNovo software using default parameters (http://proteomics.ucsd.edu/Software/PepNovo.html) to obtain amino acid sequences independently of database searches. Only PepNovo results that received a mean reliability score of at least 0.5 were accepted. These sequences were further edited according to MS BLAST rules, and an MS BLAST search was performed against the $\mathrm{nr}$ database at http://www.dove.emblheidelberg.de/Blast2/msblast.html with default parameters. The Mowse and MS BLAST scoring system were used to correctly identify proteins that had a minimum of two matched peptides and a molecular weight predicted to be in good agreement with that estimated from SDS-PAGE.

\subsection{Semiquantitative RT-PCR experiments}

Total RNA was extracted using the TRIzol reagent (Invitrogen, Carlsbad, CA, USA) according to the manufacturer's instructions. First strand cDNA was synthesized from $2 \mu \mathrm{g}$ of total RNA using Enanched Avian RT first strand Synthesis kit (Sigma). PCR primers and the thermal cycling parameters for each gene were listed in Table 3. The 18S RNA was used as the inner control. The PCR products were isolated by $1.2 \%$ agarose gel electrophoresis. All experiments were repeated two times.

\section{Results}

\subsection{Uptake of palladium by algal cells}

In our in vitro assay, cells were subjected to a single-pulse of $\mathrm{K}_{2} \mathrm{PdCl}_{4} 15 \mathrm{~h}$ after inoculation to allow cells to recover from the effect of the subculture before exposing them to the treatment. After $72 \mathrm{~h}$ of treatment, a significant amount of Pd accumulated in all treated samples (Fig. 1): Pd absorption increased when the concentration of $\mathrm{K}_{2} \mathrm{PdCl}_{4}$ increased from 0.1 to $0.5 \mathrm{mg} \mathrm{l}^{-1}$. 
Table 3

Specific primers used for RT-PCR of genes encoding the changed proteins identified by 2-DE analysis.

\begin{tabular}{|c|c|c|c|c|}
\hline Accession No. & Name & Forward primer $5^{\prime} \rightarrow 3^{\prime}$ & Reverse primer $\left(5^{\prime} \rightarrow 3^{\prime}\right)$ & $\begin{array}{l}\text { Annealing } T \\
\left({ }^{\circ} \mathrm{C}\right) / \text { cycles number }\end{array}$ \\
\hline gi|6688899 & $18 S$ rRNA & CATGATAACTCGACGGATCG & GAAGGCCAACGTAATAGGAC & $55 / 20$ \\
\hline gi|131389 & Oxygen-evolving enhancer protein 2 , precursor & TGCCGCTCTGGTGTCCTCGA & TGGGTCTCGCCGGAGTAGGC & $60 / 35$ \\
\hline gi|159476190 & Photosystem II stability/assembly factor HCF136 & CAAGCTGCCCGGTAAGGGGGTG & CCAGGATTCCAAAGCCGCGC & $60 / 35$ \\
\hline
\end{tabular}

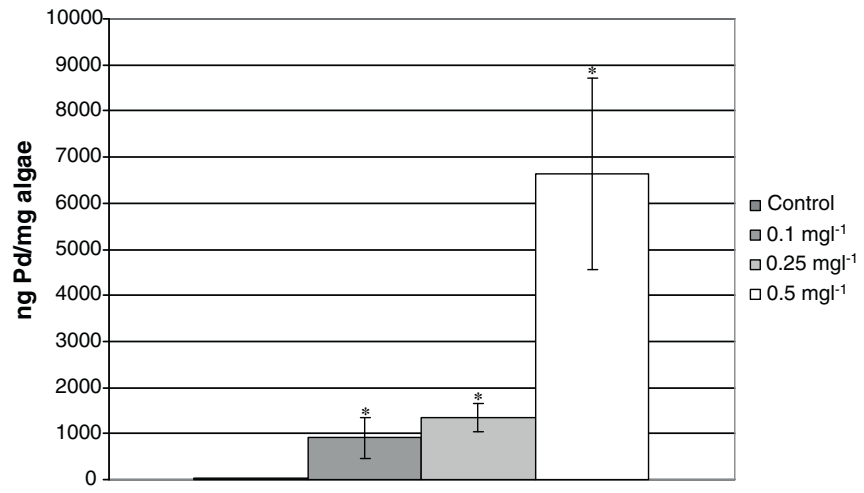

Fig. 1. Pd accumulation in treated samples. Cell samples were collected at $72 \mathrm{~h}$ after treatment with 0 (black bar), $0.1 \mathrm{mgl}^{-1}$ (grey bar), $0.25 \mathrm{mg} \mathrm{l}^{-1}$ (light grey bar) and $0.5 \mathrm{mg} \mathrm{l}^{-1}$ (white bar) of $\mathrm{K}_{2} \mathrm{PdCl}_{4}$. Values are mean $\pm \mathrm{SD}(n=3)$. Values are mean $\pm \mathrm{SD}$ $(n=3)$. Significance was revealed by Student's $t$-test $\left({ }^{*} p<0.05\right)$ referred to change between control and treated samples.

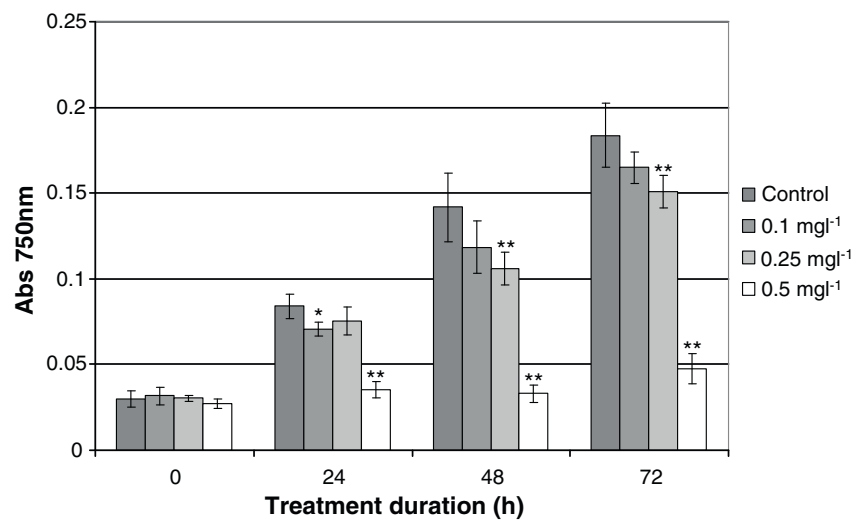

Fig. 2. Growth kinetics of Pd-treated versus control algal cells. Cell samples were collected at $24 \mathrm{~h}$ intervals after treatment with 0 (black bar), $0.1 \mathrm{mgl}^{-1}$ (grey bar), $0.25 \mathrm{mgl}^{-1}$ (light grey bar) and $0.5 \mathrm{mgl}^{-1}$ (white bar) of $\mathrm{K}_{2} \mathrm{PdCl}_{4}$. Values are mean $\pm \operatorname{SD}(n=3)$. Significance was revealed by Student's $t$-test $\left({ }^{*} p<0.05,{ }^{* *} p<0.01\right.$, referred to change between control and treated samples).

\subsection{Algal growth and photosynthetic pigment composition in response to $\mathrm{K}_{2} \mathrm{PdCl}_{4}$}

$\mathrm{K}_{2} \mathrm{PdCl}_{4}$ appeared to be an inhibitor of algal cell growth, as evidenced by the change in the growth rate (Fig. 2). When exposed treated with 0.1 and $0.25 \mathrm{mg} \mathrm{l}^{-1}$ of $\mathrm{K}_{2} \mathrm{PdCl}_{4}$ for $72 \mathrm{~h}$, cell growth showed a significant decrease ( $11 \%$ and $19 \%$, respectively) com- pared to the control. Algal growth is blocked completely at a $\mathrm{K}_{2} \mathrm{PdCl}_{4}$ concentration of $0.5 \mathrm{mg} \mathrm{l}^{-1}$.

As reported in Table $4, \mathrm{~K}_{2} \mathrm{PdCl}_{4}$ significantly decreased pigment (Chla, Chlb and carotenoids) content even at the lowest concentration. However, we did not observe any statistically significant change in the Chl $a / b$ ratio. The value of $F v / F m$ recorded during Pd treatment showed a significant decrease only at $0.25 \mathrm{mg} \mathrm{l}^{-1}$.

\subsection{Cell ultrastructural analysis in response to treatment}

TEM examination showed significant differences among the examined samples (Figs. 3 and 4).

Cells treated with $0.1 \mathrm{mg} \mathrm{l}^{-1}$ of $\mathrm{K}_{2} \mathrm{PdCl}_{4}$ were similar to controls with respect to shape, size and ultrastructure. Only $10 \%$ of cells were degenerated and, as in the controls, about $50 \%$ of chloroplasts contained starch granules. However, in numerous chloroplasts, some grana showed dilated thylakoids or isolated thylakoids that did not form grana were present. Some electron-opaque precipitates were visible in the chloroplast membranes.

In samples treated with $0.25 \mathrm{mg} \mathrm{l}^{-1}$ of $\mathrm{K}_{2} \mathrm{PdCl}_{4}$, about $40 \%$ of cells were degenerated. Cells were often swollen and their cytoplasm filled with vacuolated spaces. In the major part of the chloroplasts, grana were absent: chloroplastic membranes were severely reduced and often swollen as compared to controls. Only $30 \%$ of the chloroplasts contained starch granules. Numerous electronopaque precipitates were present in the chloroplasts, particularly associated with inner membranes.

These degenerative effects of Pd exposure were more evident at $0.5 \mathrm{mgl}^{-1}$ of $\mathrm{K}_{2} \mathrm{PdCl}_{4}$, at which concentration cells lost their crescent-moon shape and about $60 \%$ of them exhibited large vacuolated spaces. Nuclear membranes were inconspicuous and not compact, and the nucleolus was less apparent than in control cells. Most (90\%) of the chloroplasts contained no starch granules and grana; thylakoid membranes were poorly developed. In these samples, chloroplasts contained numerous electron-opaque precipitates. In very degenerated cells, these deposits were widely distributed throughout the cell and were frequently associated with mitochondria. These precipitates were visible even in samples that were stained with uranyl acetate and lead citrate excluded from the procedure for electron microscopy.

\subsection{DNA damage in response to $\mathrm{Pd}$}

To evaluate the effect of Pd on algal DNA, AFLP was performed on 0.1 and $0.25 \mathrm{mg} \mathrm{l}^{-1}$ of $\mathrm{K}_{2} \mathrm{PdCl}_{4}$-treated samples because the ultrastructural analysis showed that, at these concentrations, the cell nucleus was intact. On the contrary, at $0.5 \mathrm{mg} \mathrm{l}^{-1}$ the nuclear mem-

Table 4

Photosynthetic pigment concentration and $\mathrm{Fv} / \mathrm{Fm}$ ratio in control and treated algae.

\begin{tabular}{|c|c|c|c|c|c|}
\hline & $\mu \mathrm{g}$ Chla $/ 10^{8}$ cell & $\mu \mathrm{g} \mathrm{Chlb} / 10^{8}$ cell & $\mu \mathrm{g}$ Car. $/ 10^{8}$ cell & Chla/Chlb & $F v / F m$ \\
\hline $\mathrm{C}$ & $50.25 \pm 2$ & $6.71 \pm 0.5$ & $17.38 \pm 0.8$ & $7.51 \pm 0.7$ & $0.69 \pm 0.01$ \\
\hline $\mathrm{T} 1$ & $39.04 \pm 3^{*}$ & $5.52 \pm 0.7^{*}$ & $14.18 \pm 1^{* *}$ & $7.10 \pm 0.4$ & $0.66 \pm 0.04$ \\
\hline $\mathrm{T} 2$ & $27.24 \pm 3^{* *}$ & $3.38 \pm 0.4^{* *}$ & $10.33 \pm 0.4^{* *}$ & $8.06 \pm 0.4$ & $0.64 \pm 0.02^{* *}$ \\
\hline
\end{tabular}

C, control; T1 and T2, cells treated with $0.1 \mathrm{mg} \mathrm{l}^{-1}$ and $0.25 \mathrm{mg} \mathrm{l}^{-1}$ of $\mathrm{K}_{2} \mathrm{PdCl}_{4}$. Values showed are mean $\pm \mathrm{SD}(n=3)$.

${ }^{*} p<0.05$ (referred to change between $\mathrm{C} / \mathrm{T} 1$ and $\mathrm{T} 2$ ).

${ }^{* *} p<0.01$ (referred to change between C/T1 and T2). 

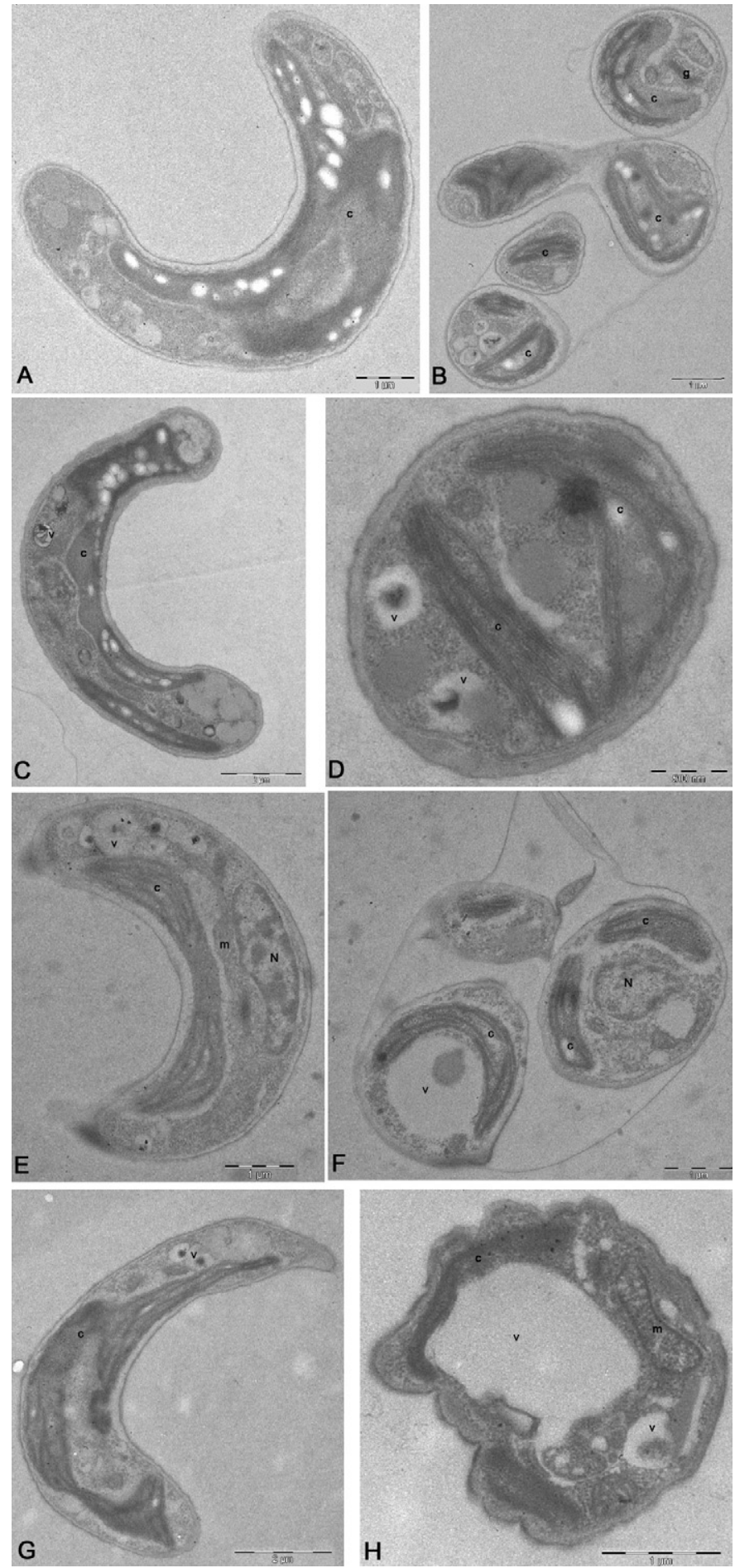

Fig. 3. TEM micrographs showing ultrastructure in control cells ( $A$ and $B$ ) and ultrastructural changes in cells treated for $72 \mathrm{~h}$ with $0.1 \mathrm{mgl}^{-1}(C$ and $\mathrm{D}), 0.25 \mathrm{mgl}^{-1}$ (E and $\mathrm{F}$ ) and $0.5 \mathrm{mgl}^{-1}$ ( $\mathrm{G}$ and $\mathrm{H}$ ) of $\mathrm{K}_{2} \mathrm{PdCl}_{4}$. V, vacuole; C, chloroplast; G, Golgi apparatus; $\mathrm{m}$, mitochondrion; $\mathrm{N}$, nucleus.

brane was inconspicuous, suggesting an imminent degeneration of this cellular organ and DNA fragmentation. Samples of three different experiments were analyzed for each tested and control sample. Six AFLP primer pair combinations were used. The DNA profile of treated algae was compared with the DNA of control samples. The analysis revealed 169 bands, 120 of which were polymorphic (Table 5). AFLP markers were found to be highly reproducible, with an overall error rate of $2-3 \%$ (Vos et al., 1995); thus the few poly-
Table 5

Number of total bands, polymorphic bands and percent of polymorphism of the 6 primer combinations used for AFLP analysis.

\begin{tabular}{lccl}
\hline Primer combinations & Total bands & $\begin{array}{l}\text { Polymorphic } \\
\text { bands }\end{array}$ & $\begin{array}{l}\text { \% of } \\
\text { polymorphism }\end{array}$ \\
\hline E01-M01 & 43 & 26 & 60 \\
E01-M02 & 35 & 22 & 63 \\
E33-M01 & 21 & 15 & 71 \\
E34-M01 & 19 & 15 & 79 \\
E34-M02 & 24 & 20 & 83 \\
E39-M01 & 27 & 22 & 81 \\
Total & 169 & 120 & \\
\hline
\end{tabular}

morphisms (four bands) detected in three control samples were considered negligible. These data indicate the genetic homogeneity of the P. subcapitata strain used in the study and its suitability for genotoxic testing.

In the case of treated samples, different polymorphic bands were detected in all tested concentration of pollutant; however, only 11 of the 120 polymorphic bands were common in almost two samples. Results of AFLP analysis were summarized in the dendrogram reported in Fig. 5 showing the genomic relationships among controls and treated samples. The similarity index among accessions varies from 1 (full genomic similarity) to 0.57 . Significant levels of genomic modification were detected starting from algae treated with $0.10 \mathrm{mg} \mathrm{l}^{-1}$ of $\mathrm{K}_{2} \mathrm{PdCl}_{4}$. A clear correlation between the detected polymorphic bands and the increasing Pd concentration was evident from the simple matching value observed from each treatment.

\subsection{2-DE analysis of $\mathrm{K}_{2} \mathrm{PdCl}_{4}$ treated algal proteins}

High-resolution 2-DE was used to separate total soluble proteins from $P$. subcapitata treated for $72 \mathrm{~h}$ with $0.3 \mathrm{mg} \mathrm{l}^{-1}$ of $\mathrm{K}_{2} \mathrm{PdCl}_{4}$. Three independent experiments and extractions were completed and, for each sample, at least triplicate gels were performed, which showed a high level of reproducibility. Representative 2-DE gels from a control and treated algal sample are shown in Fig. 6. More than 900 spots were well resolved and detected by colloidal CBB staining, over a $\mathrm{pH}$ range of $4-7$ and a size range of $10-100 \mathrm{kDa}$. All spots were matched by gel-to-gel comparison, and the difference in the relative abundance (vol.\%) of each spot was analyzed. We focused our attention on the spots whose abundance differed by \pm 1.5 fold between the treated and non-treated cells, and we selected 40 statistically confirmed protein variations between control and treated samples.

Excised spots were in-gel digested and analyzed by LC-ESIMS/MS. The proteins were identified by comparing MS/MS data to the entries of a non-redundant protein database using the MASCOT program. If protein identity had not been assigned, mass spectra were interpreted de novo by PepNovo software in order to obtain sequences for the database search. In total, 27 proteins were identified with a significant level of confidence (Table 6). The 27 identified proteins are indicated on the representative gel shown in Fig. 6. In treated versus non-treated algae, only five proteins were upregulated, while 22 proteins were down-regulated. It is noteworthy that the majority of proteins (24/27) affected by Pd were putatively localized in the chloroplast, as predicted by the PSORT/PSORT II program. The identified proteins were sorted into different functional categories as follows: photosynthesis (12), metabolism (6), disease/defence (3), protein synthesis and folding (4) and signal transduction/regulation (2).

Eleven proteins involved in photosynthesis were downregulated. These include enzymes involved in carbon fixation, such as ribulose-1,5-biphosphate carboxylase/oxigenase (RuBisCO) large subunit-binding protein subunit alpha (spot 164) and 

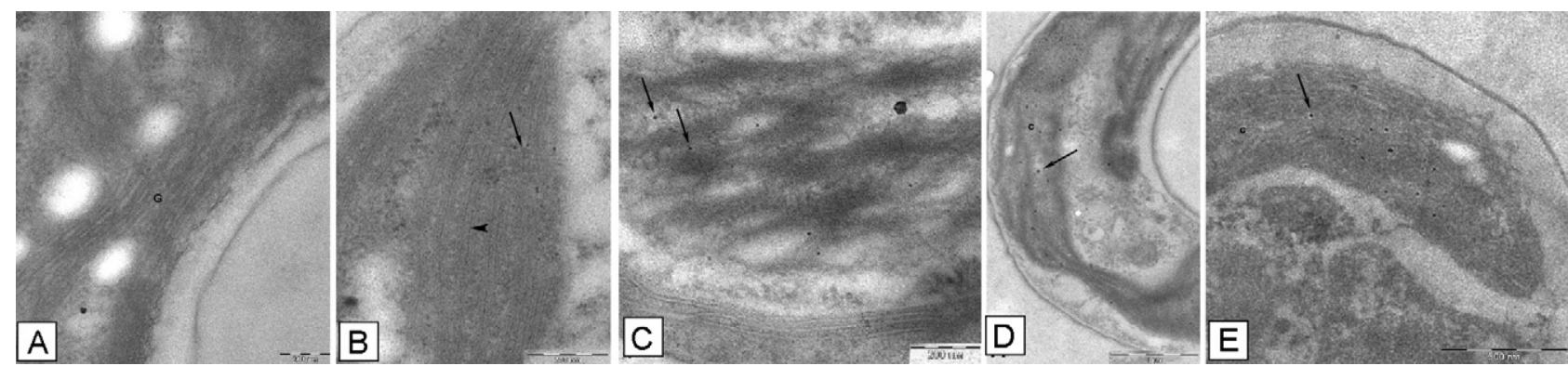

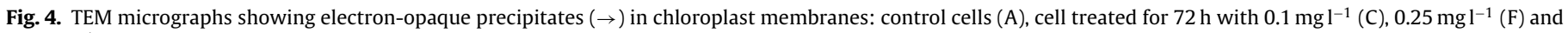
$0.5 \mathrm{mg} \mathrm{l}^{-1}$ of $\mathrm{K}_{2} \mathrm{PdCl}_{4}$ with $(\mathrm{H})$ and without (I) uranyl acetate and lead citrate in TEM procedure. $\bullet$, thylakoids; C, chloroplast; G, Golgi apparatus.

\section{SM coefficient}

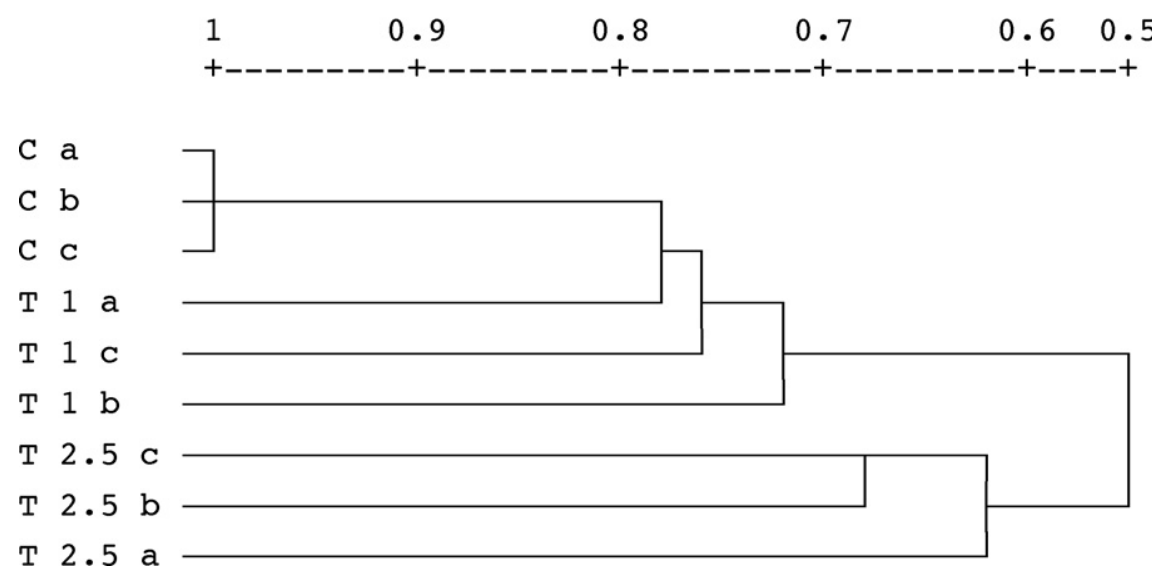

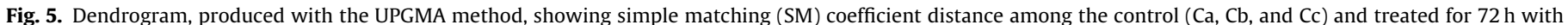
$0.1 \mathrm{mg} \mathrm{l}^{-1}$ (T1a, T1b, T1c), with $0.25 \mathrm{mg} \mathrm{l}^{-1}$ (T2.5a, T2.5b, T2.5c) of $\mathrm{K}_{2} \mathrm{PdCl}_{4}$. The dendrogram was based on a total of 169 scorable AFLP bands.

RuBisCO activase (spot 1255). In Pd-exposed cells, we also observed a decrease in chloroplast thioredoxin $m$ (TRXm, spot 566), in plastocyanin (spot 582) and in different proteins of the PSII complex, including oxygen-evolving enhancer protein 2 , chloroplastic precursor (spot 502), and four light-harvesting chlorophyll- $a / b$ binding proteins (spots 1933, 693, 1940, 566).Moreover, we found that Pd changes the abundance of three proteins involved in chloroplast post-transcriptional gene control: a translation inhibitor protein (spot 967), the chloroplast polyprotein of elongation factor Ts precursor (spot 1204) and the protein disulfide isomerase RB60 (spot 1799). Pd exposure down-regulates the chloroplast vesicleinducing protein in plastid 1 (spot 906) and the HCF136 protein (spot 326).

\subsection{Semiquantitative RT-PCR analysis}

Semiquantitative RT-PCR analyses were performed to detect the level of mRNA expression of two genes corresponding to proteins
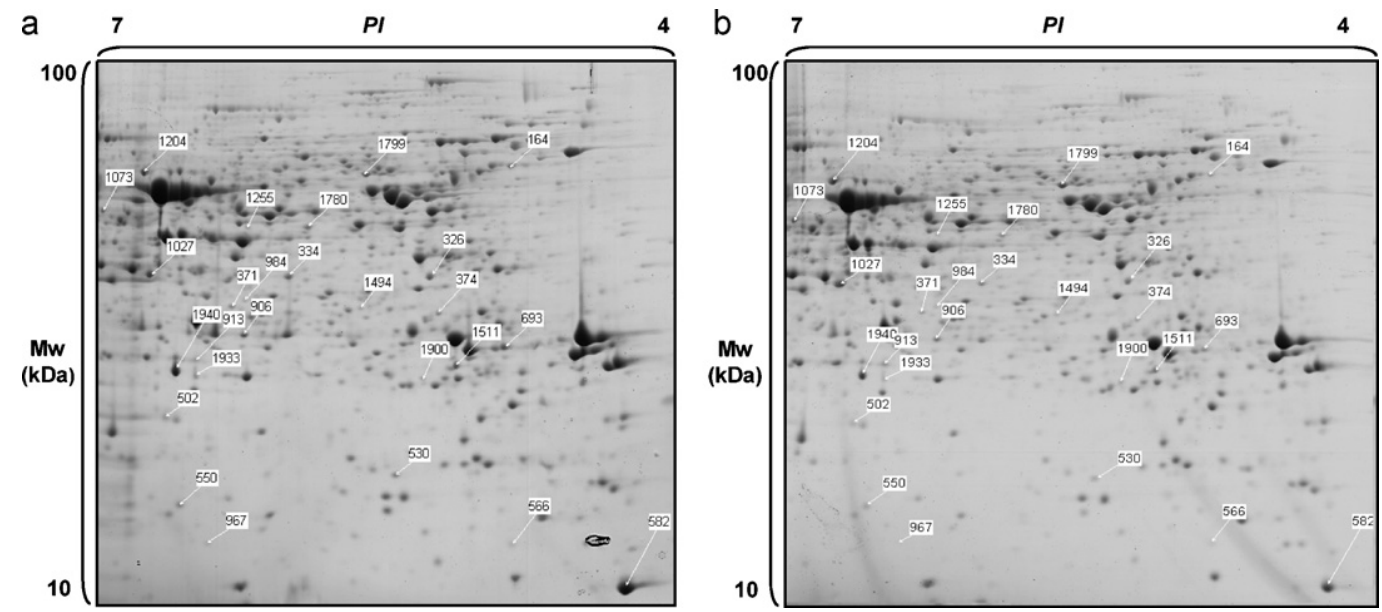

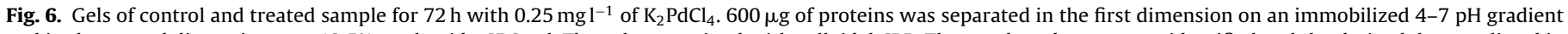

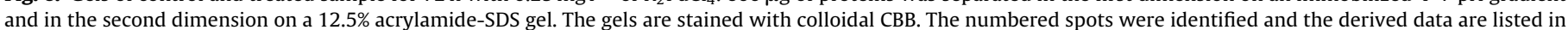
Table 5. 
Table 6

\begin{tabular}{|c|c|c|c|c|c|c|c|c|c|}
\hline \multirow[t]{2}{*}{ Protein spot } & \multirow[t]{2}{*}{ NCBI accession number } & \multirow[t]{2}{*}{ Organism } & \multirow[t]{2}{*}{ Protein name } & \multirow[t]{2}{*}{ Fold-of variation ${ }^{c}$} & \multirow[t]{2}{*}{ Loc. } & \multicolumn{2}{|c|}{ MS/MS(MASCOT) } & \multicolumn{2}{|c|}{$\mathrm{MW}(\mathrm{Da}) / \mathrm{pI}$} \\
\hline & & & & & & Score & Pept. & Theor. & Exp. \\
\hline \multicolumn{10}{|l|}{ Photosynthesis } \\
\hline 164 & gi|2493647 & Chlamydomonas reinhardtii & RuBisCO large subunit-binding protein subunit alpha & 0.3 & Chl & 96 & 2 & $61.9 / 5.6$ & $60.0 / 5.0$ \\
\hline 1255 & gi |1805719 & Chlorococcum littorale & Rubisco activase & 0.4 & $\mathrm{Chl}$ & 408 & 7 & $44.7 / 8.6$ & $55 / 6.2$ \\
\hline 913 & gi|159465721 ${ }^{\mathrm{d}}$ & Chlamydomonas reinhardtii & Ribulose phosphate-3-epimerase, precursor & 2.1 & Chl & 106 & 1 & $28.6 / 8.6$ & $45.0 / 6.1$ \\
\hline 582 & gi|130263b & Chlorella fusca & Plastocyanin & 0.5 & Chl & & & $10.3 / 4.3$ & $11.0 / 4.3$ \\
\hline 502 & gi $\mid 131389^{b}$ & Chlamydomonas reinhardtii & Oxygen-evolving enhancer protein 2 , precursor & 0.4 & Chl & & & $25.8 / 9.14$ & $23.0 / 6.6$ \\
\hline 1933 & gi $175220830^{\mathrm{b}}$ & Euglena gracilis & Light harvesting chlorophyll $a / b$ binding protein of PSII & 0.5 & Chl & & & $112.2 / 5.0$ & $23.0 / 6.5$ \\
\hline 693 & gi $27542567^{\mathrm{b}}$ & Chlamydomonas reinhardtii & Light-harvesting chlorophyll- $a / b$ binding protein Lhcb4 & 0.4 & Chl & & & $29.9 / 6.2$ & $25.0 / 5.0$ \\
\hline 1940 & gi $\mid 5902596^{d}$ & Volvox carteri f. nagariensis & Light harvesting complex a protein & 0.6 & Chl & 72 & 1 & 26.0/9.1 & $24.0 / 6.2$ \\
\hline 566 & gi $\mid 2570513^{b}$ & Oryza sativa Indica Group & Chlorophyll $a-b$ binding protein & $<0.01$ & Chl & & & 28.6/6.6 & $20.0 / 5.0$ \\
\hline 326 & gi|159476190 & Chlamydomonas reinhardtii & Photosystem II stability/assembly factor HCF136 & 0.6 & Chl & 69 & 2 & $26.0 / 9.1$ & $35.0 / 6.7$ \\
\hline 374 & gi|159491082 & Chlamydomonas reinhardtii & Phosphoglycolate phosphatase 1 & 0.6 & Chl & 170 & 3 & $36.2 / 7.62$ & $40.0 / 5.5$ \\
\hline 906 & gi $175115534^{b}$ & Chlamydomonas reinhardtii & Chloroplast vesicle-inducing protein in plastids 1 & 0.6 & Chl & & & $31.6 / 9.4$ & $26.0 / 6.0$ \\
\hline \multicolumn{10}{|l|}{ Metabolism } \\
\hline 1511 & gi|67569438 & Physcomitrella patens & NADH-ubiquinone oxidoreductase 1 , chain, putative & 0.6 & Chl & 132 & 2 & $25.6 / 5.38$ & $24.0 / 5.3$ \\
\hline 334 & gi|106869568 & Scenedesmus obliquus & Apospory-associated protein C & 0.6 & Mit & 113 & 2 & $34.0 / 6.5$ & $34.0 / 6.1$ \\
\hline 1073 & gi|48093455 & Nicotiana tabacum & ADH-like UDP-glucose dehydrogenase & 3.2 & Cyt & 487 & 10 & $41.2 / 6.2$ & $43.0 / 7.0$ \\
\hline 1780 & gi $175262773^{d}$ & Chlamydomonas reinhardtii & Malate dehydrogenase & 0.6 & Chl & 55 & 1 & $44.8 / 8.0$ & $45.0 / 6.0$ \\
\hline 1027 & gi|111608895 & Polytomella parva & Enoyl-ACP reductase & 2.2 & Chl & 218 & 3 & $35.9 / 9.4$ & $35.0 / 6.8$ \\
\hline 550 & gi $18655355^{\mathrm{b}}$ & Arabidopsis thaliana & Probable phospholipid hydroperoxide glutathione peroxidase & 0.4 & $\mathrm{Mit} / \mathrm{Chl}$ & & & $25.6 / 9.4$ & $17.0 / 6.5$ \\
\hline \multicolumn{10}{|c|}{ Signal transduction/regulation } \\
\hline 371 & gi|75225676 & Oriza sativa & Putative DNA-binding protein & 0.6 & Chl & & & $56.5 / 8.7$ & $30.0 / 6.3$ \\
\hline 1900 & gi|15228931 b & Arabidopsis thaliana & TENA/THI-4 family protein & $<0.01$ & Chl & & & $25.0 / 4.9$ & $23.0 / 5.2$ \\
\hline \multicolumn{10}{|c|}{ Disease/defence } \\
\hline 984 & gi| $75265583^{\mathrm{b}}$ & Volvox carteri f. nagariensis & Hydroxyproline-rich glycoprotein DZ-HRGP precursor & 1.7 & Chl & & & $41.0 / 12.0$ & $29.0 / 6.3$ \\
\hline 566 & gi $1729935^{\mathrm{b}}$ & Chlamydomonas reinhardtii & Thioredoxin M-type & $<0.01$ & Chl & & & $15.0 / 9.33$ & $15.0 / 5.0$ \\
\hline 1494 & gi $\mid 84029333^{b}$ & Oryza sativa & Methylglyoxalase/glyoxalase I & 2.1 & Cyt & & & $32.5 / 5.5$ & $33.0 / 5.7$ \\
\hline \multicolumn{10}{|c|}{ Protein synthesis/folding } \\
\hline 1799 & $\mathrm{gi} \mid 75318329^{\mathrm{b}}$ & Chlamydomonas reinhardtii & Protein disulfide isomerase RB60 & 1.8 & $\mathrm{Er} / \mathrm{Chl}$ & & & $58.2 / 4.8$ & $61.0 / 5.7$ \\
\hline 530 & $\mathrm{gi} \mid 21281119^{\mathrm{b}}$ & Arabidopsis thaliana & Putative FKBP type peptidyl-prolyl cis-trans isomerase & 0.3 & Chl & & & $24.0 / 8.4$ & $18.0 / 5.5$ \\
\hline 1204 & gi $75251324^{\mathrm{b}}$ & Chlamydomonas reinhardtii & Chloroplast polyprotein of elongation factor Ts precursor & 2.1 & $\mathrm{Mit} / \mathrm{Chl}$ & & & $108 / 4.5$ & $60.0 / 6.7$ \\
\hline 967 & gi $175148429^{b}$ & Gentiana triflora & Perchloric acid soluble translation inhibitor protein homolog & $<0.01$ & $\mathrm{Chl}$ & & & 19.6/7.6 & $29.0 / 5.5$ \\
\hline
\end{tabular}

Cyt, cytoplasm; Er, endoplasmic reticle; Chl, chloroplast; Mit, mitochondrion. The value ' $<0.01$ ' means that the protein spot is not present exclusively under the condition reporting this value.

a Protein founded in the EST database. The name, the molecular weight and the isoelectric point of the protein were annotated by BLAST search.

b Proteins identified by de novo analysis.

c Fold of variation, treated versus control.

d Borderline hits confirmed by de novo analysis. 


\section{HCF136}

\section{Oxygen-evolving enhancer protein 2}

\section{$18 \mathrm{~S}$}

Fig. 7. Representative image of RT-PCR mRNA expression analysis of two genes that displayed differential accumulation on 2-D protein maps (Fig. 6). Total RNA was extracted from non treated cells (C) and samples treated with $0.25 \mathrm{mg} \mathrm{l}^{-1}$ of $\mathrm{K}_{2} \mathrm{PdCl}_{4}$ (T). The housekeeping gene $18 \mathrm{~S}$ rRNA which displays constitutive expression in all samples was used as internal control.

that were found to be differentially-accumulated in Pd treated cells. As shown in Fig. 7, significant decreases at the protein level were confirmed at the mRNA level for Oxygen-evolving enhancer protein 2, precursor and Photosystem II stability/assembly factor HCF136.

\section{Discussion}

The aim of this work was to study the physiological and molecular responses of the unicellular green algae $P$. subcapitata to $\mathrm{K}_{2} \mathrm{PdCl}_{4}$ exposure. Treated cells were able to internalize Pd, as shown by atomic absorption analysis. Pd absorption affected algal growth. After $72 \mathrm{~h}$ of treatment with $0.25 \mathrm{mg} \mathrm{l}^{-1}$ of $\mathrm{K}_{2} \mathrm{PdCl}_{4}$, algal growth was significantly diminished, and it was completely blocked at $0.5 \mathrm{mg} \mathrm{l}^{-1}$. TEM observations indicate that $\mathrm{K}_{2} \mathrm{PdCl}_{4}$ begins to lead to cellular degeneration at a concentration of $0.10 \mathrm{mgl}^{-1}$ and actively does so at 0.25 and $0.5 \mathrm{mg} \mathrm{l}^{-1}$. In particular, the chloroplast appears to be the major target of the deleterious effect of Pd, with swelling, severe reduction of the thylakoid membranes and very little or no starch. Interestingly, only in treated cells, we observed electron-opaque precipitates, which increased with the exposure level. These precipitates were preferentially localized in the inner membranes of the chloroplast. Molas (1997) observed similar precipitates in Brassica oleracea leaf chloroplasts treated with Nickel. He proposed that they might be Ni-precipitates induced by the uranyl acetate used for the staining of the ultra-thin sections. As Ni and Pd belong to the same metal group, we could hypothesize that Pd-precipitates formed in the chloroplast of our samples. To test this, and to exclude the possibility that these precipitates are staining artefacts, we analyzed samples treated with $0.5 \mathrm{mg} \mathrm{l}^{-1}$ of $\mathrm{K}_{2} \mathrm{PdCl}_{4}$ in the absence of uranyl acetate and lead citrate. We again observed the presence of the electron-dense precipitates, showing that these Pd-precipitates are not due to uranyl acetate. Further experiments are necessary to confirm the preferential accumulation of Pd in the chloroplast of $P$. subcapitata.The proteomic data confirmed the deleterious effect of palladium on the chloroplast. The down-regulation of enzymes involved in carbon fixation (RuBisCO large subunit-binding protein subunit alpha and RuBisCO activase) indicates that Pd-treated algae have a lowered capacity for $\mathrm{CO}_{2}$ fixation. In Pd-exposed cells, also chloroplast TRXm was down-regulated. TRXs are involved in the regulation of carbon fixation enzymes by light, and their expression is regulated by heavy metals (Lemaire et al., 1999). In Anacystis nidulans, the disruption of the thioredoxin $m$ gene showed that this protein is essential for photosynthetic growth (Muller and Buchanan, 1989). More recently, the study of rice TRX $m$ knock-down plants suggested that this protein has an essential role in the redox regulation of chloroplast target proteins involved in diverse physiological functions. The suppression of carbon fixation in Pd-treated cells correlates with TEM observations that Pd-treated cells present very few chloroplasts with starch granules. The observed downregulation of proteins involved in the light phase of photosynthesis (plastocyanin, oxygen-evolving enhancer protein 2, chloroplastic precursor, four light-harvesting chlorophyll- $a / b$ binding proteins) could counterbalance the lowering of carbon fixation, the major sink for ATP and NAPDH, to avoid photooxidative damage. The up-regulation of two enzymes potentially involved in the oxidative pentose phosphate pathway (ribulose phosphate-3-epimerase and ADH-like UDP-glucose dehydrogenase) could be related to a compensatory mechanism to produce ATP/NADPH in Pd-treated cells. These inhibitory effects of Pd on photosynthetic apparatus were confirmed by a strong decrease of all photosynthetic pigments and of $F v / F m$ values. Overall, these data are in accordance with several reports showing that the accumulation of metals in leaves can severely inhibit the photosynthesis process, reducing the chlorophyll content, down-regulating RuBisCO and other photosynthesis-related proteins, and damaging the ultra-structure of chloroplasts (Kieffer et al., 2008; Führs et al., 2008; Ahsan et al., 2009).

Pd also seems to affect chloroplast biogenesis. In the chloroplast, where proteins of the photosynthetic apparatus and the carbonfixation enzymes are synthesized, gene expression is primarily controlled post-transcriptionally by mechanisms affecting mRNA splicing, RNA stability and translation (Mayfield et al., 1995; Barkan and Goldschmidt-Clermont, 2000). We found that Pd changes the abundance of proteins involved in this pathways: a translation inhibitor protein, the chloroplast polyprotein of elongation factor Ts precursor, the protein disulfide isomerase RB60 that can act as a regulator of chloroplast translational activation (Kim and Mayfield, 1997).Finally, Pd treatment seems to alter the assembly of the subunits into a fully functional structure that is important for chloroplast biogenesis. In fact, Pd down-regulates the chloroplast vesicle-inducing protein in plastid 1 , an essential protein involved in the formation of vesicles leading to thylakoid biogenesis: mutation of this polypeptide leads to pale-green plants that cannot grow as photoautotrophs (Kroll et al., 2001). Also the HCF136 protein, an essential factor for the stable assembly of the PSII reaction centre in Arabidopsis (Plücken et al., 2002; Nixon et al., 2010), resulted down-regulated. In Pd-treated cells, we observed an increase in glyoxalase I which plays a key role in the detoxification of methylglyoxal (MG). MG is a cytotoxic compound that is produced as a non-enzymatic byproduct of glycolysis and that accumulates in response to several abiotic stresses (Yadav et al., 2005). MG can react with and modify various molecular targets, including DNA.The Pd-induced morphological modifications could be the result of genetic alteration. In fact, AFLP analysis demonstrates that Pd induces DNA changes in algal cells, even at the lowest concentration tested. In addition, the absence of preferential mutation sites suggests that the DNA damage induced by palladium was randomly distributed in the algal genome. This is in agreement with previously conducted tests of different metals on algal cells (Labra et al., 2003) and from genotoxic tests conducted with Pd on mammalian cells (Migliore et al., 2002), suggesting that this metal is able to induce DNA oxidative damage. Generally, a high concentration of metals in cells results in the formation of a DNA adduct, named 8-oxoguanine, which is induced by reactive oxygen species (ROS, Briat and Lebrun, 1999). Most adducts can be removed by DNA repair mechanisms (Snow, 1992) and hence do not cause mutations. If misrepair occurs, guanosine may be changed to thymidine, leading to a single base mutation (Faux et al., 1992). It is possible that AFLP polymorphisms are due to mutations in restriction sequences recognised by the enzymes used, particularly those in the EcoRI target site (GAATTC) as the Msel site does not contain guanosine. The polymorphic products could also be due to random breaks in the DNA induced by palladium (Uno and Morita, 1993; Gebel et al., 1997).

In summary, our data suggest that $\mathrm{K}_{2} \mathrm{PdCl}_{4}$ is a strong stressor for $P$. subcapitata even at the lowest concentration tested. Proteomic analysis showed that Pd induces important deleterious effects on 
primary metabolism; AFLP results indicate a clear mutagenic effect on the algal genome, which is due to a direct or indirect effect and involves oxidative processes. These molecular effects are responsible for the observed decrease in algal growth, the morphological changes and the pigment and photosynthetic modifications. Overall, these data suggest that $P$. subcapitata is a sensitive organism suitable to monitor for the presence of Pd in water.

\section{Conflict of interest statement}

The authors declare that there are no conflicts of interest.

\section{Acknowledgements}

This work was partially funded by the Insubria University-FAR 2009. We would like to thank G. Terzaghi for his help with atomic absorption analysis.

\section{References}

Ahsan, N., Renaut, J., Komatsu, S., 2009. Recent developments in the application of proteomics to the analysis of plant responses to heavy metals. Proteomics 9 , 2602-2621.

Aina, R., Labra, M., Vannini, C., Marsoni, M., Cucchi, U., Bracale, M., Sgorbati, S., Fumagalli, P., Citterio, S., 2007. Thiol peptide level and proteomic changes in response to cadmium toxicity in Oryza sativa L. root. Environ. Exp. Bot. 59, 381-392.

Barkan, A., Goldschmidt-Clermont, M., 2000. Participation of nuclear genes in chloroplast gene expression. Biochimie 82, 559-572.

Battke, F., Leopold, K., Maier, M., Schmidhalter, U., Schuster, M., 2008. Palladium exposure to barley: uptake and effects. Plant Biol. 10, 272-278.

Bocca, B., Alimenti, A., Cristaudo, A., Cristallini, E., Petrucci, F., Caroli, S., 2004. Monitoring of the exposure to platinum-group elements for two Italian population groups through urine analysis. Anal. Chim. Acta 512, 19-25.

Briat, J.F., Lebrun, M., 1999. Plant responses to metal toxicity. C. R. Acad. Sci. Paris Life Sci. 322, 43-54.

Charles, M.J., Searle, G., 1991. Selenastrum Algal Growth Test: Culturing and Test Protocol at the Illinois EPA., http://www.epa.gov/ bioindicators/pdf/mpcb91_charles.pdf.

Durand, J., Teuma, E., Gómez, M., 2008. An overview of palladium nanocatalysts: surface and molecular reactivity. Eur. J. Inorg. Chem. 23, 3577-3586.

Ek, K.H., Rauch, S., Morrison, G.M., Lindberg, P., 2004. Platinum group elements in raptor eggs, faeces, blood, liver and kidney. Sci. Total Environ. 334, 149-215.

Ely, J.C., Neal, C.R., Kulpa, C.F., Schneegurt, M.A., Seidler, J.A., Jain, J.C., 2001. Implications of platinum group element accumulation along U.S. roads from catalytic-converter attrition. Environ. Sci. Technol. 35, 3816-3822.

Faux, S.P., Francis, J.E., Smith, A.G., Chipman, J.K., 1992. Induction of 8hydroxydeoxyguanosine in $A h$-responsive mouse liver by iron and Aroclor 1254 Carcinogenesis 13, 247-250.

Fomina, N.Y., Chaplygina, O.A., Shebaldova, A.D., Borodulin, V.B., 2002. Reaction of $\mathrm{K} 2 \mathrm{PdCl} 4$ with synthetic and natural nucleic acids. Russ. J. Gen. Chem. 72, 704-709.

Führs, H., Hartwig, M., Molina, L.E.B., Heintz, D., Van Dorsselaer, A., Braun, H.-P., Horst, W.J., 2008. Early manganese-toxicity response in Vigna unguiculata L.: a proteomic and transcriptomic study. Proteomics 8, 149-159.

Fumagalli, A., Faggion, B., Ronchini, M., Terzaghi, G., Lanfranchi, M., Chirico, N., Cerchi, L., 2010. Platinum, palladium, and rhodium deposition to the Prunus laurus cerasus leaf surface as an indicator of the vehicular traffic pollution in the city of Varese area. Environ. Sci. Poll. Res. 17, 665-673.

Gebel, T., Lantzsch, H., Pleßow, K., Dunkelberg, H., 1997. Genotoxicity of platinum and palladium compounds in human and bacterial cells. Mutat. Res. 389, 183-190.

Gomez, B., Palacios, A., Gomez, M., Sanchez, J.L., Morrison, G., Rauch, S., McLeod, C., Ma, R., Caroli, S., Alimonti, A., Petrucci, F., Bocca, B., Schramel, P., Zischka, M., Petterson, C., Wass, U., 2002. Levels and risk assessment for humans and ecosystems of platinum-group elements in airborne particles and road dust of some European cities. Sci. Total Environ. 299, 1-19.

Gueguen, C., Koukal, B., Dominik, J., Pardos, M., 2003. Competition between alga (Pseudokirchneriella subcapitata), humic substances and EDTA for Cd and Zn control in the algal assay procedure (AAP) medium. Chemosphere 53, 927-934.

Hoppstock, K., Sures, B., 2004. In: Merian, E., Anke, M., Ihnat, M., Stoeppler, M. (Eds.), Elements and their Compounds in the Environment. , second ed. Wiley-VCH, Weinheim, pp. 1047-1086.

Jarvis, K.E., Parry, S.J., Piper, J.M., 2001. Temporal and spatial studies of autocatalystderived platinum, rhodium and palladium and selected vehicle derived trace elements in the environment. Environ. Sci. Technol. 35, 1031-1036.

Jensen, K.H., Rauch, S., Morrison, G., Lindberg, M., 2003. Platinum group elements in the feathers of raptors and their prey. Arch. Environ. Contam. Toxicol. 42 338-347.
Kieffer, P., Dommes, J., Hoffman, L., Hausman, J.F., Renaut, J., 2008. Quantitative changes in protein expression of cadmium-exposed poplar plants. Proteomics $8,2514-2530$.

Kim, J., Mayfield, S.P., 1997. Protein disulfide isomerase as a regulator of chloroplast translational activation. Science 278, 1954-1957.

Kroll, D., Meierhoff, K., Bechtold, N., Kinoshita, M., Westphal, S., Vothknecht, U.C., Soll, J., Westhoff, P., 2001. VIPP1, a nuclear gene of Arabidopsis thaliana essential for thylakoid membrane formation. Proc. Natl. Acad. Sci. U.S.A. 98, 4238-4242.

Labra, M., Di Fabio, T., Grassi, F., Regondi, S.M., Bracale, M., Vannini, C., Agradi, E., 2003. AFLP analysis as biomarker of exposure to organic and inorganic genotoxic substances in plants. Chemosphere 52, 1183-1188.

Lemaire, S., Keryer, E., Stein, M., Schepens, I., Issakidis-Bourguet, E., GérardHirne, C., Miginiac-Maslow, M., Jacquot, J.P., 1999. Heavy-metal regulation of thioredoxin gene expression in Chlamydomonas reinhardtii. Plant Physiol. 120, 773-778.

Marsoni, M., Bracale, M., Espen, L., Prinsi, B., Negri, A.S., Vannini, C., 2008. Proteomic analysis of somatic embryogenesis in Vitis vinifera. Plant Cell Rep. 27, 347-356.

Mayer, P., Kuhel, R., Nyholm, N., 1997. A simple in vitro fluorescence method for biomass measurements in algal growth inhibition tests. Water Res. 31, 2525-2531.

Mayfield, S.P., Yohn, C.B., Cohen, A., Danon, A., 1995. Regulation of chloroplast gene expression. Annu. Rev. Plant Physiol. Plant Mol. Biol. 46, 147-166.

Migliore, L., Frenzilli, G., Nesti, C., Fortaner, S., Sabbioni, E., 2002. Cytogenetic and oxidative damage induced in human lymphocytes by platinum, rhodium and palladium compounds. Mutagenesis 17, 411-417.

Molas, J., 1997. Changes in morphological and anatomical structure of cabbage (Brassica oleracea L.) outer leaf and in ultrastructure of their chloroplasts caused by an in vitro excess of nickel. Photosynthetica 34, 513-522.

Moldovan, M., Veschambre, S., Amouroux, D., Bénech, B., Donard, O., 2007. Platinum, palladium, and rhodium in fresh snow from the Aspe valley (Pyrenees Mountains, France). Environ. Sci. Technol. 41, 66-73.

Moran, R., Porath, D., 1980. Chlorophyll determination in intact tissues using N,Ndimethylformamide. Plant Physiol. 65, 478-479.

Muller, E.G., Buchanan, B.B., 1989. Thioredoxin is essential for photosynthetic growth. The thioredoxin $\mathrm{m}$ gene of Anacystis nidulans. J. Biol. Chem. 264, 4008-4014.

Nixon, P.J., Michoux, F., Yu, J., Boehm, M., Komenda, J., 2010. Recent advances in understanding the assembly and repair of photosystem II. Ann. Bot. 106, 1-16.

Pan, S., Zhang, G., Sun, Y., Chakraborty, P., 2009. Accumulating characteristics of platinum group elements (PGE) in urban environments. China Sci. Total Environ. 407, 4248-4252.

Parry, S.J., Jarvis, K.E., 2006. In: Zereini, F., Alt, F. (Eds.), Palladium Emission in the Environment. Springer.

Plücken, H., Müller, B., Grohmann, D., Westhoff, P., Eichacker, L.A., 2002. The HCF136 protein is essential for assembly of the photosystem II reaction center in Arabidopsis thaliana. FEBS Lett. 532, 85-90.

Porra, R.J., Thompson, W.A., Kreidemann, P.E., 1989. Determination of accurate extinction coefficients and simultaneous equations for assaying chlorophylls $a$ and $b$ extracted with four different solvents: verification of the concentration of chlorophyll standards by atomic absorption spectrometry. Biochim. Biophys. Acta 975, 384-394.

Ravindra, K., Bencs, L., van Grieken, R., 2004. Platinum group element in the environment and their health risk. Sci. Total Environ. 318, 1-43.

Rohlf, F.J., 1993. NTSYS-pc. Numerical Taxonomy and Multivariate Analysis System (version 2.02). Execter Publisher Ptd., Setauket, NY.

Snow, E.T., 1992. Metal carcinogenesis: mechanistic implications. Pharmacol. Ther. $53,31-65$.

Strasser, R.J., Srivastava, A., Govindjee, L., 1995. Polyphasic chlorophyll a fluorescence transient in plants and cyanobacteria. Photochem. Photobiol. 61, 32-42.

Tuit, C.B., Ravizza, G.E., 2000. Anthropogenic platinum and palladium in the sediments of Boston Harbor. Environ. Sci. Technol. 34, 927-932.

Uno, Y., Morita, M., 1993. Mutagenic activity of some platinum and palladium complexes. Mutat. Res. 298, 269-275.

USEPA, 1994. Short-term Methods for Estimating the Chronic Toxicity of Effluents and receiving Waters to Freshwater Organisms, third ed, EPA/600/4-91/002.

Vannini, C., Marsoni, M., Domingo, G., Antognoni, F., Biondi, S., Bracale, M., 2009. Proteomic analysis of chromate-induced modifications in Pseudokirchneriella subcapitata. Chemosphere 76, 1372-1379.

Vos, P., Hogers, R., Bleeker, M., Reijans, M., van de Lee, T., Hornes, M., Freijters, A., Pot, J., Peleman, J., Kuiper, M., Zabeau, M., 1995. AFLP: a new concept for DNA fingerprinting. Nucleic Acids Res. 21, 4407-4414.

Yadav, V., Mandhan, R., Dabur, R., Chhillar, A.K., Gupta, J., Sharma, G.L., 2005. An antifungal fraction from Escherichia coli. J. Med. Microbiol. 54, 375-379.

Zechmeister, H.G., Hagendorfer, H., Hohenwallner, D., Hanus-Illnar, A., Riss, A., 2006. Analyses of platinum group elements in mosses as indicators of road traffic emissions in Austria. Atmos. Environ. 40, 7720-7732.

Zereini, F., Wiseman, C., Puttmann, W., 2007. Changes in palladium, platinum, and rhodium concentrations, and their spatial distribution in soils along a major highway in Germany from 1994 to 2004. Environ. Sci. Technol. 41, 451-456.

Zimmermann, S., Messerschmidt, J., von Bohlen, A., Sures, B., 2005. Uptake and bioaccumulation of platinum group metals (Pd, Pt, and $\mathrm{Rh}$ ) from automobile catalytic converter materials by the zebra mussel. Environ. Res. 98, 203-209. 